\title{
The Use of Javanese Language in Conversation by Sex
}

\author{
Nia Auliyah \\ Post Graduate English Applied Linguistic Program \\ Universitas Negeri Medan, Indonesia \\ E-mail: auliyahnia@gmail.com
}

\begin{abstract}
This study was conducted to determine the use of Java language in the community. Individuals function as part of a harmonious family or group. Men and women have differences in speech. Culture is also bound in the distinction, in a Javanese society known for its low voice level and the use of a phrase called 'low' and 'high' krama that enable speakers to show distance, familiarity and respect among community members as well as courtesy of the use level of speech in Javanese. Sources of data were taken from the interviews of Javanese tribal, orally. The results of this study are there is no difference between women and men in communicating, that there is only difference of speech, if talking to the elderly use acts of krama speech while in peers use acting speech ngoko. Each level choosen own functions, a few people who have a high status, medium used for pushing the conversation among fellow peers or younger, ngoko to the closest state between the speaker and the speech
\end{abstract}

Keywords: Javanese, speech level, ngoko 'low' and manners' high

\section{INTRODUCTION}

Language is the ability to communicate with others. In the social life of language function has traditionally can be said as a means of verbal communication. However, the function of language is not merely as means of communication. For sociolinguistic concept of language is a tool that functions to convey the mind alone is considered too narrow (Abdul Chaer, 2004: 15) [3]. Beside it, a study of gender is important to the study of language, and the first step to gender study is to explore the difference between men and women. So there are a differences between man and woman in the used varieties of languge especially in Javanese.

In the Java community, in general they use Java language in daily communication. Java language, in several levels,: Ngoko Java language, the Java language Associate, Java language Krama. Java language has many variations, both social variation, as well as regional variations. Therefore, the Java community is very careful in the language. They were very attentive to diversity of languages used. Level speech into a system of delivery of a sense of propriety code in which there are elements of specific vocabulary, certain syntactical rules, morphology, and specific phonology.

\section{REVIEW OF LITERATURE}

\section{A. Definition of Sociolinguistics}

Sociolinguistics is a branch of linguistics that are interdisciplinary in sociology, with the object of study the relationship between the language of the social factors within a speech community. sociolinguistics not only addresses the problem of language in a society but language with social behavior. In the sociolinguistic, language as a social system and communication system as well as the cultural part of society, inter-language with the culture and community speakers can not be separated from one another or can not stand alone

Which deals with sociolinguistics, the conference sosiolinguistikberpendapat that, issues that were examined or discussed in sociolinguistics are:

a. Social identity of the speaker

b. Social identity of the listeners involved in the communication process,

c. Said social environment where events occurred,

d. Synchronic and diachronic analysis of social dialects,

e. Different social assessment by the speakers will be the behavior of the forms of speech,

f. Depth variation and linguistic diversity

g. Practical application of sociolinguistic research.

\section{B. Male-Female Difference in Using Language}

a. Differences in intonation

Women often like to speak in a high-pitch voice because of physiological reason, but scientists point out that this Also associates with women "s" timidity "and" emotional instability ". Besides the high-pitch voice, women prefer to use a reverse accent as well.

\section{b. Differences in Vocabulary}

We can notice that men and women tend range to choose different words to show Reviews their feelings. For example, when a woman is frightened, she usually shouts out, "I am frightened to death"! If you hear a man says this, you "ll think he is a coward and womanish.

\section{c. Adjectives}

Women like to use many adjectives, such as adorable, charming, lovely, fantastic, heavenly, but men seldom use 
them. When a woman leaves a restaurant, she will say "It" sa gorgeous meal ". If a man wants to express the same idea, he may only say, "It" sa good meal.

d. Adverbs

A differences in the use of adverbs between men and women. Women tend range to use such adverbs like awfully, pretty, terribly, vastly, quite, so; men like to use very, utterly, really. Women are very conscious about Reviews their status, and they long for a better position in society, so they try to improve Themselves, Including using standard language. On the other hand, men are powerful, Including the lower-class men.

\section{c. The Determinants of Java Language Variety}

Social factors, such as social status, age, education level, gender, and so on, being situational factors, who the speaker, to whom he speaks, when, where. Suwito (1983: 20) mentions language communities as the speech community, which means a society or a group of people who have the verbal repertoire of relatively equal and have the same assessment to the norms of the use of the language used in the community.

1. Ngoko speech level is Java language speech level that reflects the taste is between $\mathrm{P}$ to $\mathrm{T}$. This means that $\mathrm{P}$ does not have inhibitions (jiguh pekewuh) against T. So, for someone who wants to express its familiarity to $\mathrm{T}$. ngoko speech level that should be used.

- Peers

- People who are already familiar

- older people to young people

2. Manners rate is the rate speech said that emits the full sense of manners. This speech levels indicate shyness (pekewuh) si $\mathrm{P}$ to $\mathrm{T}$, because $\mathrm{T}$ is the unknown, rank, aristocracy, authoritative, and others.

- Students and teachers - of young people to older people

- Children to parents

- Employees with boss

3. Associate Level is the level of secondary speech or manners and polite ngoko. show feelings are mediocre. The assumption that the medium is a marker that the wearer was the village. His account is as follows:

I changed into kula

- Kowe converted into sampeyan or Samang

\section{Methodology}

Method in this research using descriptive qualitative, which seeks to provide and explain various aspects of language that emerged as the fact that No or phenomena that are empirically live on speakers, so that the resulting commit or to users who are recorded in the form of the description of the language used to say its nature as a portrait: exposure to such fact (Sudaryanto, 1993: 62) [6] then this study using techniques refer to that conduct watch to the data studied. This means that researchers not involved in the use of language that is used as the data in the study. Methods of data collection in this study using the method refer (observation / observation). The method is a method of data collection with listening to the use of language (Sudaryanto:133) [6]

\section{RESULT}

From a few examples can be seen that there is a differences in conversation used the Java language for woman, it can be conclusion seen that women and men alike - each chosen to use a diversity of languages in the Java language in the circumstances, with whom to talk to. Another difference is only in the lower female intonation according to several conditions as well as the choice of words more than men. A man have a high voice and a large part in the election said the man was more simple.

Javanese speak in communicating who speaks and to whom. because there is no difference between women and men in communicating, that there is only difference of speech, if talking to the elderly use acts of krama speech while in peers use acting speech ngoko. But in the other situation in Javanese language woman and man who speak soft and better in choose word in communicating it show thier high status.

\section{CONCLUSION}

Conclusion of the study, women use softer language and to choose the appropriate circumstances in which they are located, while men do not think too much about language as what is used. But in the Java language men and women tend to choose what kind of language is used because it shows the dignity and high status. Factors affecting the Java language diversity is Poedjosoedarmo division level According to Supomo Javanese speech levels are divided into three levels, namely ngoko speech level, speech level manners and speech level intermediate. Each level choosen own functions, a few people who have a high status, medium used for pushing the conversation among fellow peers or younger, ngoko to the closest state between the speaker and the speech.

\section{REFERENCES}

[1] Burns,RB.1995.IntroductiontoResearchMethods.London: Longman Chin, NB \& Wigglesworth, G. 2007. Bilingualism: An Advanced Resource Book. New York: Routledge.

[2] Cummings, Louise. 2007. Pragmatics; a Multidisciplinary Perspective (trans. Eti Sitiawati, et al.). Yogyakarta: Student Library.

[3] Chaer, Abdul. 2005. Psikolinguistik kajian teoritik. Jakarta: Rineka Cipta

[4] Holmes,J.2002.AnIntroductiontoSociolinguistics.Longman: London and New York.

[5] Moleong, Lexy J. 2014. Qualitative Research Methods. Bandung: PT Young Rosdakarya.

[6] Sudaryanto. 1993. Metodedan Aneka Teknik Analisis Bahasa" Pendidikan Wahana Kebudayaan Secara Linguistik". Yogyakarta: Duta Wacana University Press

[7] Poedjosoedarmo, Soepomo., Gloria Soepomo, B. Dwijatmiko, Soepadma Padmasoemarta, \& dan Fx. Amrih Widodo. (1982) Kedudukan dan Fungsi Bahasa Jawa. Yogyakarata: Departemen Pendidikan dan Kebudayaan Proyek Penelitian Bahasa dan Sastra Indonesia dan Daerah.

[8] Pradanta, Sukmawan wisnu. Pemakaian Alih Kode Dan Campur Kode Bahasa Jawa di Pasar Elpabes Proliman Balapan Surakarta (Sebuah 
